\title{
GESETZ
}

\section{URBILD UND MYTHOS}

\author{
VON
}

W.F. OTTO

MCMLI

J.B.METZLERSCHE VERLAGSBUCHHANDLUNG STUTTGART 
ISBN 978-3-476-98833-1

ISBN 978-3-476-98832-4 (eBook)

DOI 10.1007/978-3-476-98832-4

(C) 1951 Springer-Verlag GmbH Deutschland

Ursprünglich erschienen bei J. B. Metzlersche Verlagsbuchhandlung und

Carl Ernst Poeschel Verlag G.m.b.H., Stuttgart 